\title{
Guerra dos Farrapos (1835-1845): entre o fato histórico e suas apropriações
}

\author{
Farrapos' War (1835-1845): between historical fact and its \\ appropriations
}

Ânderson Marcelo Schmitt ${ }^{1}$

\begin{abstract}
Resumo: Neste artigo trataremos da Guerra dos Farrapos - ou Revolução Farroupilha -, ocorrida no Rio Grande do Sul entre os anos de 1835 até 1845. Esta guerra civil é o fenômeno histórico mais debatido pela historiografia sulrio-grandense, despertando o interesse de vários pesquisadores acadêmicos e diletantes. Além deste interesse por parte dos pesquisadores, a Guerra dos Farrapos passou para o calendário de comemorações oficial no Estado do Rio Grande do Sul, possuindo uma semana com o seu nome - Semana Farroupilha -, na qual se celebra e se ritualiza as ações de estancieiros, em sua grande maioria senhores de escravos, que levaram a cabo uma luta fratricida em busca de maior espaço de representação política e econômica junto ao poder central. Desta forma, entendemos que a comemoração e ritualização da Guerra dos Farrapos no 20 de setembro - data que marca o início do confronto - não pode ser realizada sem compreendermos qual a sua real importância histórica, o que representou o conflito para os contemporâneos e quais os interesses que estavam em jogo. Dispusemos para esta pesquisa da imensa possibilidade historiográfica que temos à disposição e da documentação primária disponibilizada pelo Arquivo Histórico do Rio Grande do Sul, bem como dos exemplares do periódico oficial farroupilha.
\end{abstract}

Palavras-chave: Crise, Guerra dos Farrapos, Gauchismo.

1 Doutorando em História pela Universidade Federal de Santa Catarina, Florianópolis/SC, Brasil. Bolsista CNPq. E-mail: anderson.schmitt@uffs.edu.br

(c) EY Direito autoral e licença de uso: Este artigo está licenciado sob uma Licença Creative Commons. Com essa licença você pode compartilhar, adaptar, para qualquer fim, desde que atribua a autoria da obra, forneça um link para a licença, e indicar se foram feitas alterações. 


\begin{abstract}
In this article we will discuss the Farrapos' War, which is also called the Farroupilha Revolution - occurred in Rio Grande do Sul between the years 1835 to 1845 . This civil war is the most debated historical phenomenon by the sulriograndense historiography, arousing the interest of several academic researchers and dilettantes. In addition to this interest by researchers, the Farrapos War went to the official celebrations calendar in the State of Rio Grande do Sul, having a week in its name - Farroupilha Week in which rancher's old habits are celebrated and ritualized, being mostly of them slaveholders, who carried out a fratricidal struggle in search of greater space for political and economic representation in the central government. Thus, we understand that the celebration and ritualizing of Farrapos War, on September 20 - the date that marks the beginning of the confrontation - can not be accomplished without understanding its real historical significance, representing the conflict to contemporaneity and what interests were at stake. We have had a great historiographical possibility which is available and the primary documentation provided by the Rio Grande do Sul Historical Archive, as well as copies of the Ragamuffin official journal.
\end{abstract}

Keywords: Crisis, Farrapos' War, Gauchismo.

\title{
Palavras iniciais
}

Embora vários estudos demonstrem o contrário, ainda nos chama a atenção o quanto a Guerra dos Farrapos, ocorrida na província do Rio Grande do Sul, entre 1835-1845, passa ano a ano para o imaginário social como um conflito que colocou, de um lado, um Império usurpador e desprezível contra uma província que pegou em armas para defender seus interesses contra "eles", que não respeitavam minimamente a dignidade e honra da população sul-riograndense. Deve se ater ao fato de que a Guerra dos Farrapos não foi uma guerra da população rio-grandense contra o Império brasileiro, mas sim, de uma parte dos chefes militares ou para-militares contra outros chefes sul-riograndenses, que continuaram a defender o governo imperial e foram auxiliados, principalmente a partir de 1842, com levas trazidas de outros cantos do Brasil, uma vez que neste ano estavam erradicadas rebeliões que agitavam outros confins do Império - estas sim, muitas vezes com caráter popular. ${ }^{1}$

Anualmente, informações jornalísticas e midiáticas sobre o fenômeno farroupilha costumam abarrotar os meios de comunicação rio-grandenses. ${ }^{2}$ Tão conhecida quanto a inundação de informações pertinentes a essa guerra, é a constatação nos meios acadêmicos de que estas assertivas sobre o decênio bélico são cercadas de lutas interpretativas que buscam legitimar uma imagem do conflito. 
Tendo de se preocupar com os levantes surgidos em diversas regiões, foi na província de São Pedro do Rio Grande do Sul que os líderes imperiais experimentaram a maior dificuldade em debelar os ímpetos de seus súditos que formavam a parte da província rebelada. Por praticamente dez anos durou o movimento em solo rio-grandense - que não deixou de se estender por Santa Catarina ${ }^{3}$-, e se conformou como a mais duradoura guerra enfrentada pelo Império brasileiro.

As comemorações da Semana Farroupilha, se alastram pelo Estado do Rio Grande do Sul - e para além dele - durante a semana que antecede a data do 20 de setembro, rememorando o dia e ritualizando a data em que as forças rebeldes farroupilhas adentraram em Porto Alegre e destituíram o presidente de província Antônio Rodrigues Fernandes Braga (1805-1875), dando início à guerra civil. A própria existência desta data comemorativa, que é institucionalizada desde a década de 1970, demonstra o quanto este conflito é importante para a construção da sociedade sul-rio-grandense. Se não nos termos de importância histórica quando do acontecimento, pois não ocorreram modificações significativas nas instituições políticas ou econômicas depois da guerra, mas demonstra sim, sua validade como fenômeno a ser rememorado e ritualizado por todas as camadas da população, remetendo-as a tempos e contextos históricos que não mais existem ou que nunca tenham existido.

Segundo a avaliação de Guazzelli, o discurso de "crise" perpassa a criação desta identidade regional no Rio Grande do Sul, ligado a um sentimento de "nostalgia". Desta forma, os problemas (crises) enfrentados pelo Estado são invariavelmente atribuídos "a motivos externos ao Rio Grande, gerados no âmbito dos que se aproveitam do Estado e não retribuem os benefícios alcançados, o que muitas vezes é diretamente associado ao Estado nacional, controlado por "eles". ${ }^{4}$ A "crise" também estava presente no discurso dos líderes farroupilhas quando de suas queixas sobre as formas do governo imperial gerir as decisões que diziam respeito à nossa região.

Pensando o conceito de região, neste momento, entendemos que este não se trata apenas de um espaço determinadamente geográfico. Reckziegel, considerando as ideias de Armand Frémont, indica que este "concebe região como um 'espaço vivido que compreende elementos administrativos, históricos, ecológicos, econômicos, mas também, e mais profundamente, psicológicos"”. Assim, "reconhece-se a existência de um espaço social, de um espaço vivido em nível regional, portador de cargas mais obscuras em que se misturam as escórias do afetivo, do mágico, do imaginário". 5

Para Bourdieu, a procura por "critérios objetivos de identidade regional" deve tomar o cuidado de não "fazer esquecer que, na prática social, estes critérios (...) são objeto de representações mentais, quer dizer, de atos de percepção e de apreciação, de conhecimento e de reconhecimento em que os 
agentes investem os seus interesses" e seus pressupostos; e de "representações objetivas, em coisas (emblemas, bandeiras, insígnias, etc.) ou em atos, estratégias interessadas de manipulação simbólica que tem em vista determinar a representação mental que os outros podem ter destas propriedades e dos seus portadores". ${ }^{6}$ De forma geral, o que "está em jogo é o poder de impor uma visão do mundo social através dos princípios de di-visão que, quando se impõe ao conjunto do grupo, realizam o sentido e o consenso sobre o sentido e, em particular, sobre a identidade e a unidade do grupo".?

A identidade que nos é apresentada como a do povo gaúcho nos remete a uma distinção entre o "eu", neste caso "nós", e o "outro", neste caso "eles", e busca ser uma resposta à imposição de uma sociedade nacional brasileira homogeneizada pelos meios de comunicação de massa. Podemos pensar, neste sentido, que o fenômeno não se dá mais pelos termos da tradição farroupilha, mas apenas como expressão de distinção cultural de uma sociedade que tende à homogeneização, como lembrou Rubem Oliven já na década de $1980 .{ }^{8}$ Entretanto, as inúmeras referências que se fazem ao episódio quando das épocas de crise do Estado e em suas rememorações anuais, não nos deixam pensar que o fenômeno não possui importância decisiva quando se busca um mito fundador para a identidade e cultura rio-grandense.

Em termos históricos, a rememoração da Guerra dos Farrapos remete a um tempo mítico, um tempo mal definido, um tempo no qual os acontecimentos parecem ser intocáveis e imutáveis, não propensos a novas interpretações que levariam a reconstruções de fatos e de ações dos atores sociais reais. Busca-se, dessa forma, uma redenção no passado mítico sul-rio-grandense. O tempo mítico apresenta uma "estrutura circular", tratando-se de um "tempo reversível - se não através do mito, que realiza o retorno em sua própria narrativa ou repetição cíclica, ao menos através do 'rito', que corresponde a um retorno ritual às origens. " No lastro do tempo mítico, não falta à identidade rio-grandense nem mesmo seu panteão de heróis, formado por políticos, militares, estancieiros e corsários. Obviamente aqui se remete aos heróis Bento Gonçalves, David Canabarro, Antônio de Souza Neto, Giuseppe Garibaldi, entre outros. $\mathrm{O}$ acontecimento e os heróis são alcançados a partir do rito, que é, como dito, outra particularidade do tempo mítico, repetido a cada Semana Farroupilha, no qual as pessoas parecem se reencontrar com suas pretensas origens, inserindo-se em um tempo circular, um tempo renovável e reabilitável, um tempo, enfim, a-histórico.

\section{Antecedentes, causas e a sociedade no momento da eclosão do conflito}

Passemos a falar um pouco sobre o significado da Guerra dos Farrapos em sua época, buscando interpretar os acontecimentos em sua conjuntura, como fenômeno específico que foi. Uma análise da Guerra dos Farrapos se faz válida 
quando acontecimentos recentes e cotidianos a situam nos embates culturais de nossos dias, a utilizando de uma forma genérica.

Não foram poucas as vezes em que a coroa portuguesa e, posteriormente, o Império brasileiro, invadiram ou barraram incursões de seus vizinhos de língua espanhola do sul. Nestas contendas, os sul-rio-grandenses sempre estiveram na frente de batalha das operações naquelas paragens. Assim, após a independência uruguaia, este país continuou, nas palavras de um contemporâneo, "povoado por brasileiros que ali possuem propriedades de grande valor". Mais do que isso, os sul-rio-grandenses conservaram, ainda nas palavras do mesmo contemporâneo, "naquele Estado as mais estritas relações, incluídas as de aliança de família; foram ou são casados com senhoras do Estado Oriental ou são descendentes de famílias daquele Estado não poucos oficiais do nosso Exército." ${ }^{10}$ As invasões luso-brasileiras de 1811 a 1828 foram vitais para a ocupação da região setentrional do Uruguai, uma vez que as lideranças de língua portuguesa "aprovavam e encorajavam uma ocupação imediata para substanciar maiores reivindicações territoriais". Além do mais, ao se organizar estâncias, a "população errante da fronteira podia ser controlada. A maior parte dos estancieiros a adquirir terras na fronteira era composta de oficiais da milícia". ${ }^{11}$ Estes chefes milicianos faziam parte da organização militar do Estado português, mesmo não sendo de estancieiros a maioria dos líderes militares. ${ }^{12}$ Ao analisar as tropas luso-brasileiras de início dos oitocentos, podemos afirmar que "as forças armadas portuguesas de fins do século XVIII e início do XIX não apresentavam a racionalização e o corporativismo dos atuais exércitos profissionais". Eram sim, "tropas que dependiam de lealdades anteriores, e o quadro de oficiais era composto menos pela formação profissional do que pelas hierarquias sociais vigentes, dependendo de favorecimentos clientelares". ${ }^{13}$ Regra, esta, que continuou condicionando as relações castrenses ao menos até a Guerra do Paraguai (1864-1870).

A camada de latifundiários que predominava na campanha rio-grandense passou, destarte, a reivindicar voz ativa nas deliberações políticas do Império brasileiro. Desta forma, como aponta Dolhnikoff, esta camada fez parte da construção e da unidade do Estado brasileiro, uma vez que a formação deste Estado foi possível "não pela ação de uma elite bem-formada, articulada ao governo central, mas graças a um arranjo institucional que foi resultado dos embates e negociações entre as várias elites regionais que deveriam integrar a nação". ${ }^{14}$

No Ato Adicional de 12 de agosto de 1834, buscou-se organizar esta mediação entre o poder central e as províncias. Para isso, se instituíram as Assembleias Legislativas nas províncias - em lugar dos conselhos provinciais, que possuíam poderes apenas reivindicatórios. As Assembleias seriam responsáveis pelos assuntos locais. No Rio Grande do Sul, a eleição dos cidadãos que comporiam o Legislativo ocorreu no dia 7 de abril de 1835 e foi 
formada em sua maioria por pessoas ligadas ao partido liberal, do qual viriam os principais chefes farroupilhas do movimento que estava para se iniciar. Entre os eleitos titulares e suplentes estavam Marciano Pereira Ribeiro - que também foi o primeiro presidente do Legislativo provincial -, José de Paiva Magalhães Calvet, Francisco de Sá Brito, José Mariano de Matos, Bento Gonçalves da Silva, Domingos José de Almeida, José Gomes de Vasconcelos Jardim, José Pinheiro de Ulhoa Cintra, Bento Manuel Ribeiro e Pedro José de Almeida: todos conhecidos farroupilhas. ${ }^{15}$ Não obstante, portanto, as tentativas de articulação - ou controle - do poder central com a criação da Assembleia provincial, existiam outros descontentamentos que fizeram com que a revolta eclodisse meses depois.

A Guerra da Cisplatina (1825-1828) - que erigiu "a Província Cisplatina em Estado independente, uma espécie de "estado-tampão" interposto entre o Brasil e as Províncias Unidas"16 - além de ter desgastado os cofres imperiais, desgostou os oficiais rio-grandenses, que viram nas deficiências da liderança do enviado Barbacena, as razões pela catastrófica campanha brasileira no conflito. $\mathrm{O}$ desagrado de serem relegados a chefes subalternos em um terreno no qual possuíam grande conhecimento desagradou os chefes rio-grandenses. Somou-se a isso o descontentamento com o impedimento do transporte do gado platino para o Rio Grande do Sul, o que prejudicou os latifundiários e charqueadores da província. Deliberando neste sentido, Piccolo entende que a

derrota em Ituzaingó seria crucial para a deterioração das relações entre sul-rio-grandenses e o governo do Rio de Janeiro. A radicalização das posições se acentuaria depois de 1831, quando os que se diziam 'liberais' se deram conta de que a abdicação de dom Pedro não nacionalizara o governo, continuando a ser perceptível a influência de portugueses em decisões de caráter político tomadas. A liberalização na estrutura governamental definida no ato adicional de 1834 não foi considerada suficiente para que os interesses do Rio Grande do Sul fossem contemplados. ${ }^{17}$

Assim, aparentemente os questionamentos das instituições monárquicas tal qual funcionavam estavam na raiz da eclosão da Guerra dos Farrapos, mas como veremos, não necessariamente podemos interpretar dessa forma.

No manifesto de Bento Gonçalves e de Domingos José de Almeida, de 29 de agosto de 1838, no qual se expunha as causas que levaram ao levante, os líderes criticaram a política imperial: "Exibiam certamente as províncias a quota respectiva, onde incluíamos a nossa para as despesas de guerra; mas o arbítrio nos tirava com violência em gado vacum e cavalar e em exigência de todo mil vezes mais do que cumpria quotizar-nos proporcionalmente". Ainda tratando dos estigmas que restaram das campanhas na Banda Oriental, Bento 
e Almeida manifestaram que "não nos pagou o governo Imperial o que se nos tirou a título de compra ou de empréstimo, e muito menos ressarciu as nossas perdas ocasionadas por um estado de coisas de que só ele era culpado". ${ }^{18}$ Sempre se utilizou, portanto, do discurso de exploração para buscar dar legitimidade ao movimento.

O Rio Grande do Sul, cujo produto mais importante da época, o charque, visava abastecer os mercados do centro do Império, possuía determinada dependência dos valores pelos quais os comerciantes do centro pagariam para receber este produto. Assim, viram suas aspirações malogradas pela política econômica imperial, que protegia e dava aval para entrada do produto vindo das antigas colônias espanholas do Rio da Prata, que já possuía proteção dentro de seus países por ser o principal produto nacional, e não secundário, como no caso brasileiro. Deste modo, considerando-se que as "províncias do norte" eram as culpadas pela alta carga tributária que recaia sobre o Rio Grande do Sul, se reivindicava um sistema tributário que favorecesse o comércio dos produtos locais diante dos seus concorrentes platinos "através da redução do imposto de exportação de couros de $15 \%$ para $5 \%$, da redução do imposto de importação do sal de \$240 réis para $\$ 050$ réis por alqueire e da instituição de um imposto de importação de charque que protegesse o produto nacional". ${ }^{19}$ A reforma do sistema tributário realizada pela regência não modificou esta relação econômica, mostrando-se incapaz de "alinhar os interesses dos setores exportadores aos interesses dos setores produtores para o mercado interno brasileiro". ${ }^{20}$

Entretanto, a questão do charque não foi central para a deflagração da revolta. Segundo Leitman, os $15 \%$ que pesavam sobre o gado entrado no Rio Grande do Sul vindo da Banda Oriental foram abolidos em junho de 1835, o que garantiu que os "charqueadores que dependiam comercialmente do Rio de Janeiro, o maior centro consumidor de charque e couro" conservassem-se leais. Por sua vez, parte dos estancieiros da campanha, também prejudicados pelo imposto, já tinha "aderido aos farroupilhas". Para instigar os descontentamentos dos estancieiros, neste mesmo ano se "estabeleceu um imposto de 10 [mil] réis sobre cada légua quadrada de pastagem.” Dessa forma, taxava-se não os bens produzidos, mas o meio de produção. Além disto, "o novo orçamento estabeleceu pequenos impostos sobre esporas, estribos e outros objetos necessários aos rio-grandenses da campanha". ${ }^{21}$

Além da questão fiscal, no quesito político não se aceitava que os administradores enviados para a província fossem sempre naturais de outras regiões do Império, pois não possuíam ligações com os chefes rio-grandenses e, assim, não faziam parte das redes políticas e sociais que ensejavam a participação local no processo político brasileiro. A questão principal, parece ter sido o afastamento de parte da elite militar do centro de poder, uma vez que a ordem era estabelecida "através das proeminências locais". Ou seja, os políticos na capital imperial "ao mesmo tempo assentiam aos interesses dos 
proprietários em lugarejos de todo o país e asseguravam que as elites locais transmitissem suas opiniões" aos ocupantes dos cargos políticos imperiais, que eram lançados a partir da própria base local. ${ }^{22}$

$\mathrm{Na}$ esteira do desmembramento da província Cisplatina do Império brasileiro, as relações entre Bento Gonçalves e Juan A. Lavalleja - caudilho que participou do processo de independência do Uruguai - aumentaram quando Fructuoso Rivera tomou posse da presidência uruguaia, em 1830. Os dois caudilhos tiveram combinação para iludir o governo imperial. Para poder continuar prestando auxílio à Lavalleja, criou-se o boato de que as manobras militares deste caudilho eram importantes para poder derrubar Rivera e reincorporar a Cisplatina ao Império brasileiro. O governo imperial aderiu à causa proposta por Bento Gonçalves e Lavalleja, e apenas com derrotas militares do líder oriental em 1832, o Império retirou a autorização de auxílio. Denúncias chegadas de Montevidéu também fizeram despertar as suspeitas do Império quanto às reais intenções dos compadres da fronteira. Ao mesmo tempo, Bento Gonçalves espalhava boatos de que Rivera planejava revoltar a província e envolvê-la no sistema republicano. ${ }^{23}$

Tendo denúncias destes envolvimentos de Bento Gonçalves, foi este chamado à corte, acusado "de estar tramando a revolução com proteção dos orientais". Bento Gonçalves, que possuía o cargo de comandante da fronteira de Jaguarão, estava inserido na conjuntura limítrofe, e como os demais chefes militares, era responsável "por conseguir homens, cavalos, suprimentos e alianças políticas, que eram os fatores indispensáveis para a guerra no sul". Assim, ao se analisar atentamente as tramas da elite na fronteira rio-grandense, interpretamos que "o estopim para a deflagração da revolta, em 1835, contra o presidente da província, foram as destituições sofridas por Bento Gonçalves do Comando da Fronteira de Jaguarão (no extremo sul), e por Bento Manuel Ribeiro do Comando da Fronteira de Alegrete (no oeste)". ${ }^{24} \mathrm{O}$ afastamento dos dois chefes do aparato militar, que lhes garantia influência na sociedade, foi determinante para que se colocasse em prática a deposição do presidente provincial em 1835. Portanto, a questão do imposto do charque e suas matériasprimas, dos impostos sobre a légua de terra, o tema da derrota militar da Cisplatina, na qual os chefes militares rio-grandenses foram subalternizados, poderiam ser toleradas pelas lideranças da província. O que não poderia ser tolerado pelos chefes sul-rio-grandenses era o afastamento dos caminhos que levavam até o contato com o poder central do Rio de Janeiro. Uma vez destituídos de suas posições de destaque nos comandos de suas respectivas fronteiras, Bento Gonçalves e seu tocaio Bento Manuel Ribeiro, começaram a tramar a deposição do representante imperial que estava mais próximo deles, o presidente da Província, Fernandes Braga. Apoiaram-se em correligionários liberais que ocupavam posições importantes na Campanha e que também saíam prejudicados com o afastamentos dos tocaios de suas funções, pois assim, 
ações na fronteira ficariam prejudicadas, como o contrabando de gado sem pagamento de impostos para ambos os lados.

O maior exemplo que podemos dar sobre a importância deste afastamento de parte dos líderes da província para a deflagração da Guerra dos Farrapos, foi a atitude de Bento Manuel logo após a invasão da capital, Porto Alegre, e a deposição do presidente Fernandes Braga, em 20 de setembro de 1835. Os farroupilhas aguardaram por dois meses qual seria a resolução do governo imperial: repressão pelas armas ou aceitação de um movimento que sempre se disse não-separatista. Nesta esteira, o que ocorreu foi o envio para a presidência da província de um rio-grandense, José Araújo Ribeiro, que era bem-quisto entre os liberais. Seus laços mais estreitos, entretanto, se davam com Bento Manuel Ribeiro. ${ }^{25}$ Desta forma, à sua chegada na província sucedeuse a mudança de lado de Bento Manuel, que deixou as fileiras farroupilhas e passou a os debelar, defendendo os legalistas. A razão é clara: para ele, naquele momento, estavam repostas as condições para que participasse do jogo político imperial, passando pelo presidente da província e chegando no governo central. A mesma razão explica a sua passagem novamente para o lado farroupilha, em 1837, após a deposição de Araújo Ribeiro pelo governo imperial. O substituto de Araújo Ribeiro, Antônio Elzeário de Miranda Britto, não participava da rede clientelar de Bento Manuel, logo, se juntar novamente aos farroupilhas significava lutar por mudanças que viessem a aumentar sua esfera de influência na política e assim, aumentasse também seu poder como chefe influente e reconhecido dos habitantes da campanha. Portanto, a imagem de Bento Manuel que devemos ter em mente, não é a de um simples traidor em que nem farroupilhas nem legalistas poderiam depositar confiança, assim como é colocado muitas vezes pelas construções históricas que se fazem dele. Mas suas ações devem ser entendidas como as de um ator social que sabia muito bem utilizar dos mecanismos que tinha à disposição para tirar vantagem e aumentar o poderio do seu cabedal militar.

Bento Manuel não é figura rememorada atualmente nas comemorações da Semana Farroupilha, ou quando é lembrado, é no sentido de apontar o inimigo, o traiçoeiro, o não-confiável, o que queria colocar tudo a perder. Isso quando não se aponta o fato dele ser sorocabano, e não nascido na província de São Pedro, conformando o "outro", o "ele", que não possui a pretensa honra dos briosos nascidos no Rio Grande do Sul.

Uma vez deflagrada a revolta, esta passou de um caráter contestatório para separatista, em 11 de setembro de 1836, quando Antônio de Souza Neto proclamou a "República Rio-Grandense" em Seival, quase fronteira com o Uruguai. A proclamação se deu pela intensa contradição que estava ocorrendo na conjuntura do período. Os farroupilhas não estavam conseguindo convencer a regência da importância de suas reivindicações e esta, por sua vez, não demonstrava interesse em negociar com os rebeldes. Para se resolver 
a contradição de "lutar contra a mesma bandeira que estavam erguendo", se resolveu por proclamar uma República, que à época era termo utilizado para denominar não um modelo de Estado específico, mas sim de um governo que seria voltado para o interesse público. ${ }^{26}$ Entretanto, apesar das diversas visões políticas e ideológicas dos seus representantes, uma das únicas ideias que parece ter sido unânime entre os líderes farroupilhas foi a concepção da "brasilidade" do movimento. Em inúmeras proclamações de seus líderes em vários momentos do conflito, se declarava que a independência era temporária, e que assim que as demais províncias também se rebelassem, seria formada uma Federação de Estados independentes, que conformariam a tão aclamada nação brasileira defendida pelos farroupilhas. Um exemplo cabal desta concepção está no episódio da invasão de Laguna pela marinha e exército farroupilha. Logo após tomarem a cidade, na metade do ano de 1839, proclamaram a República Juliana na província catarinense, que teria caráter independente, mas federada à província rio-grandense. ${ }^{27}$ Portanto, a invasão à Santa Catarina esconde muito mais do que o interesse em acesso a um porto para comércio. Da mesma forma, as demais rebeliões provinciais do período regencial eram apoiadas pela imprensa farroupilha, ${ }^{28}$ porque minimizavam o número de soldados que poderia ser enviado para combater no Rio Grande do Sul, mas também porque demonstrava que os demais confins do vasto território brasileiro estavam se levantando contra o Império pretensamente usurpador.

O interesse, portanto, girava em torno da descentralização do poder, que tornaria possível aos líderes locais uma maior autonomia na gerência dos assuntos regionais. Se não se podia acessar o centro do poder pelas vias clientelares, então se fizesse a descentralização, na qual as decisões fossem tomadas em nível regional e local, mantendo, obviamente, a ordem social vigente. Esta característica da política rio-grandense e quiçá imperial, retoma aos tempos da colônia e perpassa a criação do espaço colonial ibérico nas Américas. A metrópole portuguesa, sem poder para bancar seus exércitos profissionais na Europa e muito menos na América, relegava estes poderes aos mandatários locais, que seriam comandantes de milícias e de ordenanças, comandando a população que estava sob seu âmbito de domínio. Esta força paramilitar - que passou a se chamar "Guarda Nacional” a partir de 1831 não recebia soldo, a não ser quando de destacamentos para outras regiões, e o fardamento e armamento utilizado era proveniente do próprio soldado ou do chefe militar ao qual estava ligado. ${ }^{29}$ Esta forma de atuação da Coroa portuguesa no sul das Américas fica evidente quando tratamos, por exemplo, da figura de Rafael Pinto Bandeira. Este comandante utilizou-se de prerrogativas particulares para expulsar as tropas espanholas que invadiram a Capitania de São Pedro na década de 1760, e também neste momento, como bem demonstrou Tiago Gil, aproveitou-se para aumentar o seu leque de relações, premiando amigos com distribuição de terras e permissão de contrabando, 
perseguindo outros chefes que queriam disputar com ele o poder miliciano ou realizar contrabandos sem informa-lo. ${ }^{30} \mathrm{O}$ poder de proteger o território português, e pós-1822, brasileiro, fez com que estes mandatários locais contassem com o apoio da Coroa portuguesa e do Império brasileiro, mesmo que o poder central tivesse informações sobre suas ações irregulares. Era mais seguro ao centro fazer de conta que não via irregularidades em nível local, do que levar as denúncias às últimas consequências e poder perder o apoio destes chefes, que era tão importante no cenário conturbado de disputa entre as coroas ibéricas no pré-independência e entre os estados independentes no período posterior. Esta relação se tornou conturbada, como vimos, quando grande parte dos chefes provinciais se sentiu prejudicada pelo afastamento do centro de decisões políticas, que somado a outros fatores, levaram à eclosão da Guerra dos Farrapos. O que os chefes regionais e locais esperavam era o prosseguimento da política que permitia grande abertura para negociações individuais e favorecimentos para si e para seus protegidos.

\section{Projeto de Constituição, intrigas...}

Bento Gonçalves foi eleito pelas câmaras municipais aderentes, como presidente interino da recém-criada República, cargo que deveria ocupar até a reunião de uma Assembleia Constituinte, que deveria ser convocada por Bento Gonçalves assim que a conjuntura de guerra permitisse. Após tentativas frustradas de instalação da Assembleia, esta se fez apenas em 1842, quando a capital farroupilha já havia passado por Piratini, Caçapava e se encontrava em Alegrete. Nas segundas e terceiras sessões foi organizada uma série de comissões para debater projetos legislativos referentes a diversos aspectos da organização farroupilha. Entre estas comissões estava a que ficou encarregada de apresentar um projeto de Constituição para aprovação. O grupo da minoria, que formava oposição ao grupo de Bento Gonçalves, entendeu que este estava tentando manter o mesmo grau de poder que possuía até o momento, por pedir ele a suspensão das garantias políticas e individuais, com o pretexto de estar o governo sobre ameaça de conspiração por parte de aliados de Bento Manuel Ribeiro. A suspensão das garantias individuais permitia que houvessem invasões a casas de suspeitos de serem opositores e que fossem tomados bens mesmo sem a autorização do proprietário. Ademais, o líder farroupilha possuía plano de realizar deportações e, para alcançar seus objetivos, passou a ameaçar seus opositores inclusive com partidas de soldados armados que estavam em Alegrete. Deste modo, a minoria se viu acossada e por vezes deixou de aparecer às sessões. ${ }^{31} \mathrm{O}$ projeto de Constituição apresentado pela comissão responsável não chegou a ser votado pela Assembleia. As oposições e perseguições fizeram com que não houvesse tempo para isso.

No projeto de Constituição farroupilha constava que para ser candidato a qualquer dos cargos eletivos da República, o pretendente deveria professar a 
religião do Estado, o catolicismo..$^{32}$ Isto ia de encontro às ideias republicanas que os farroupilhas queriam fazer passar, pois demonstrava que a tradição monárquica do Império se fazia muito presente. Neste era que a religião era fator diferencial para as disputas políticas, ao passo que a tradição de 1789 já havia separado a crença da política.

O projeto de Constituição farroupilha mantinha a barreira à cidadania, pois o fator censitário se fazia extremamente presente. Para votar para deputado da República, o cidadão deveria ter uma renda mínima de 200 mil réis anuais, e para ser candidato a tal cargo, a exigência que se fazia era que tivesse uma renda anual mínima de 300 mil réis. Os cargos acima da deputação, como senadores e o próprio presidente da República, seriam eleitos de forma indireta, a partir de Assembleias municipais que escolheriam os eleitores e da Câmara dos deputados. A renda mínima para ser escolhido presidente era de $600 \mathrm{mil}$ réis anuais. ${ }^{33}$

As desavenças entre os farroupilhas fizeram com que o projeto não fosse levado à votação. Após o encontro da Assembleia Constituinte, os destinos da República rio-grandense estavam traçados. Os farroupilhas se digladiavam internamente em ofensas pessoais e mortes entre si próprios, como o caso do assassinato de Onofre Pires por seu primo Bento Gonçalves, em duelo após Onofre tê-lo chamado de ladrão, ou a morte de Paulino da Fontoura, que à época foi atribuída ao grupo chefiado por Bento Gonçalves. ${ }^{34}$

Some-se a isso a chegada do Barão de Caxias, futuro Duque, para ocupar o cargo de presidente da província e comandante-das-armas do Império. Caxias soube como poucos utilizar da estratégia militar, mas seu forte diferencial foi acirrar as intrigas existentes entre os rebeldes. Negociava o acordo de paz com uma facção e fazia com que a outra ficasse sabendo, o que era interpretado como traição entre os farroupilhas. ${ }^{35}$ Assim ele fez quando, por exemplo, Antônio de Souza Neto e Bento Gonçalves pediram a anistia ao Imperador D. Pedro II. A ação foi vista como traição pelo grupo de David Canabarro. Caxias ainda utilizou de outro subterfúgio para apaziguar os ânimos na província: a boa e velha compra. Encontram-se documentos que comprovam as, abre aspas "despesas secretas para a pacificação da província", onde se especificam valores repassados aos líderes farroupilhas que se retiraram do conflito. Todas as facções farroupilhas se faziam representadas nesta lista. ${ }^{36}$

Ainda sobre o projeto de Constituição, como se não bastasse o já dito sobre o caráter pouco democrático que possuía, ele não abolia a escravidão, dizendo que seriam cidadãos rio-grandenses "todos os homens livres nascidos no território da República". As análises feitas sobre o conflito, no que toca a participação de escravos, costumam focar o episódio de Porongos, caindo em discussões pouco frutíferas sobre se de fato ocorreu ou não a traição de David Canabarro aos Lanceiros Negros, baseando-se na confiabilidade do documento apontado como comprovador do triste episódio. ${ }^{37}$ Ainda que seja bastante 
discutida na historiografia, a traição de Porongos parece ainda encontrar dificuldades de introdução nos meios acadêmicos e nas escolas. Verifica-se, assim, uma dissonância entre as discussões acadêmicas e o fazer didático do professor nos diversos níveis. Outras análises que tratam da questão racial na guerra, costumam afirmar que as participações de cativos se deram porque os negros fugiam de seus donos para se apresentar aos farroupilhas em troca de promessas de liberdade ao fim do conflito. Sobre Porongos, sem querer de modo algum esgotar a discussão, o relato mais importante, ao meu ver, é a afirmação de Domingos José de Almeida, já na década de 1860, quando diz que estava se sentindo ameaçado por antigos correligionários, que não queriam que ele colocasse em prática o antigo projeto de escrever a História da Guerra dos Farrapos. A ameaça vinha principalmente, segundo ele, de exfarroupilhas que estavam envolvidos no episódio de Porongos. ${ }^{38}$ Quanto às fugas para apresentação para as fileiras farroupilhas em troca de liberdade, estas com certeza ocorreram e as fontes históricas as comprovam. Entretanto, o universo de possibilidades para a participação negra no conflito é muito mais complexa e não se resume a ações padronizadas e facilmente inteligíveis. Em tese recente, Daniela Vallandro de Carvalho analisou detalhadamente casos de participação negra no conflito, demonstrando que os cativos possuíam uma gama de interesses próprios, podiam acompanhar seus senhores por lealdades pessoais ou como forma de facilitar sua fuga ${ }^{39}$ Ainda, existem casos de negros que chegaram a ocupar cargos de chefia nos exércitos milicianos em razão do desempenho em campo de batalha e tato demonstrado para as atividades bélicas. Algo muito debatido na historiografia era o destino dado aos escravos que estavam com os farroupilhas quando da assinatura do acordo de anistia, em fevereiro de 1845, já que no documento do acordo, o Império ficou comprometido a dar liberdade a todos os escravos que tivessem lutado pelos farroupilhas. ${ }^{40}$ Nos últimos anos, duas pesquisas avançaram muito no sentido de elucidar esta questão, sendo estes os trabalhos de Juremir Machado e Daniela Vallandro. Ficou-se demonstrado que os negros que fugiram e se apresentaram aos farroupilhas para lutar em troca de sua liberdade foram entregues pelos chefes rebeldes ao fim do conflito ao Barão de Caxias, chefe imperial, e foram remetidos ao Rio de Janeiro, onde desempenharam atividades para o governo imperial. ${ }^{41}$ Assim, os negros, que formaram o núcleo do exército farroupilha já que não tinham para onde ir - ao passo que os demais soldados se retiravam para suas casas e seus afazeres quando dos ínterins da guerra - foram piamente traídos por seus chefes. Seus sonhos de liberdade no Rio Grande do Sul acabaram com o barco que os levou para o Rio de Janeiro. Ficou-se demonstrado que, para os líderes farroupilhas que fizeram o acordo de paz, povo que tem virtude também pode acabar a guerra sendo escravo.

No que se refere à arregimentação das tropas que lutaram na Guerra dos Farrapos, costuma-se abordar o tema de duas maneiras: a primeira, 
enfatiza um discurso de que as tropas farroupilhas seriam formadas de forma espontânea pelos habitantes da província, que lutariam contra um Império usurpador; ${ }^{42}$ a segunda corrente, mais crítica ao movimento, trata esta questão abordando a falta de um projeto democrático dos farroupilhas e afirmando que os recrutamentos eram feitos à força, e que os combatentes não passavam de "massa de manobra" dos grandes chefes milicianos. ${ }^{43}$ Estudos recentes, muito influenciados pela micro-história italiana, principalmente na figura de Giovanni $\mathrm{Levi}^{44}$, tem demonstrado a complexidade das participações de pessoas comuns neste conflito. ${ }^{45}$ Fica evidente que estes indivíduos não eram tão propícios a se apresentar ao exército como queria a primeira corrente, e nem eram tão passivos como quer provar a segunda. Para elucidar a questão, precisamos ter claro em mente que a maioria dos soldados era formada por pessoas comuns, sem grandes propriedades e muitas vezes agregados em algumas estâncias. Estas pessoas dependiam do seu trabalho braçal para angariar o seu sustento e de sua família. Assim, o recrutamento poderia gerar prejuízos aos soldados, principalmente quando realizados nos períodos de colheita. Saber gerir esta questão também fazia um chefe miliciano ser reconhecido como um "bom chefe". Desta forma, não raras vezes era dada licença para os soldados se retirarem do campo de batalha e cuidarem de seus afazeres pessoais. Estes soldados, por sua vez, sabiam das vantagens de se apresentar a um chefe miliciano quando este estava precisando recrutar tropas para alguma contenda. Se em tempos de necessidade, de arregimentação, os cidadãos se apresentassem de forma espontânea a este chefe, ficava evidente que ele aceitava fazer parte deste grupo, ser "gente" deste chefe, e poderia esperar vantagens em tempos de paz, bem como estar protegido de perseguições de outros chefes menores, pois ele passava a contar com a proteção de uma figura respeitada. ${ }^{46}$ Assim se explica, por exemplo, o fato de Bento Manuel Ribeiro, no início da guerra, conseguir arregimentar grande quantidade de homens na região da campanha. ${ }^{47}$ Assim se explica também, porque quando da vinda de Caxias para o Rio Grande do Sul, este tenha buscado, e conseguido, o auxílio militar de Bento Manuel, por mais que Caxias tivesse recomendações do Imperador de não se aproximar daquele chefe. Caxias entendeu que sem o cabedal militar ${ }^{48}$ de Bento Manuel, seria impossível vencer de forma cabal a guerra no interior da província. Desta forma, temos uma hierarquia de posições clientelares, que ia desde o próprio Imperador, passando por ministros, presidentes de província, altos oficiais milicianos, oficiais subalternos e chegando na massa geralmente pobre da população. Em cada um desses contatos havia um jogo de interesses muito grande. Assim, quebra-se com a ideia, geralmente difundida pela corrente historiográfica crítica da Guerra dos Farrapos, de que os soldados eram "massa de manobra". Igualmente, não se apresentavam cegamente a estes oficiais superiores, mas apenas na medida em que vislumbravam possibilidades de ascensão econômica e social. Eles possuíam interesses, sabiam jogar com o 
cenário volátil dos tempos de guerra, sabiam como ativar os mecanismos de ação que lhes ofertava vantagens presentes e futuras.

A ação social, deste modo, citando Levi, "é vista como o resultado de uma constante negociação, manipulação, escolhas e decisões do indivíduo, diante de uma realidade normativa que, embora difusa, oferece muitas possibilidades de interpretações e liberdades pessoais". ${ }^{49}$ Portanto, se a autonomia das decisões dos sujeitos não pode ser entendida como totalmente desvinculada das opções colocadas pela conjuntura, também não é por completo condicionada por uma macroestrutura. $\mathrm{O}$ que dá espaço para o surgimento de estratégias sociais por parte dos sujeitos.

\section{Palavras finais}

Nestas páginas, procuramos evidenciar que a Guerra dos Farrapos como movimento heroico e que pode simbolizar a união do Estado todo, nunca existiu, e esta imagem deve ser totalmente combatida. Por sua vez, também não podemos cair na tentação de, na tentativa de desmitifica-la, a tratarmos por um viés maniqueísta, considerando determinados atores sociais conformados em falsos heróis como vilões. Os avanços metodológicos e teóricos do conhecimento acadêmico não nos permitem mais a realização de um estudo sério sem que os sujeitos envolvidos sejam entendidos como realmente são: atores sociais inseridos no contexto histórico do século XIX. Se quisermos atribuir como de sua responsabilidade a criação imagética e identitária para a qual serviram posteriormente, estaremos caindo, no mínimo, no erro do anacronismo.

$\mathrm{Na}$ busca da sua desmitificação identificam-se muitas barreiras, a começar pelas comemorações da Semana Farroupilha nas escolas, onde muito dificilmente o professor da área de Humanas é convidado para fazer uso da palavra. Desta forma, reproduzindo discursos prontos e transportando os alunos para um plano atemporal e a-histórico, onde prevalecem heróis estancieiros, os parcos avanços conseguidos pelos professores nos minguados períodos dedicados à História regional, são praticamente anulados.

Esta guerra marca ainda um fato um tanto quanto idiossincrático. Se no passado dos homens, são os vencedores que possuem o privilégio de contar sua história, relegando os perdedores ao plano do esquecimento, nesta, o que se deu foi exatamente o contrário. Derrotados no campo militar, sem a mínima organização política, com seus chefes literalmente matando-se por ofensas pessoais, foram os farroupilhas que conseguiram relegar sua memória para as gerações futuras. Dessa forma, o historiador que quiser fazer a "história à contrapelo", terá de lidar com o desconforto de perceber que está trabalhando, de fato, com uma história que já nasceu de pelo virado.

No processo de homogeneização que é tentado dar aos integrantes do atual território do Rio Grande do Sul, pouco se levou em conta as 
singularidades, por exemplo, do processo de imigração europeia da segunda metade do XIX ou da primeira metade do XX. Estes, inclusive, buscaram fazer parte da intitulada tradição rio-grandense, aderindo aos CTGs e à pilcha nos períodos de comemoração. O processo de construção da memória da Guerra dos Farrapos fica claro em um fato interessante: as nomenclaturas de três cidades no Rio Grande do Sul. São elas: David Canabarro, Bento Gonçalves e Garibaldi. Os três territórios, no momento do conflito, pouco conheciam o elemento europeu. Eram regiões do norte/nordeste do Rio Grande do Sul com presença de indígenas e caboclos. Apenas algumas décadas depois do fim da Guerra dos Farrapos é que surge a imigração em massa de italianos que vão se alocar na serra gaúcha. Desta forma, Bento Gonçalves, líder miliciano, latifundiário e senhor de escravos, circula desde cedo o imaginário das pessoas que nascem na região serrana, que trabalharam desde cedo com a agricultura de subsistência em pequenas propriedades e em grande maioria não possuíram escravos. Esta construção aproxima-se a o que Jacques Le Goff denominou de "cultura histórica", e que se expressa na relação com que determinada sociedade tem com o passado. Porém, não se limita apenas à História como disciplina, mas "outras formas de conhecimento e expressão cultural que tenham como referência o passado. Literatura, arte, cultura popular, monumentos e muitas outras manifestações simbólicas que estabeleçam relações com o tempo estão presentes na constituição dessa categoria". ${ }^{50}$

Em termos gerais, se o imaginário da Guerra dos Farrapos é utilizado para diferenciar e dar traços singulares ao Rio Grande do Sul, isso não pode, à primeira vista, ser motivo de crítica. Em um país de dimensões continentais como o Brasil, reforça-se a ideia de que a nação só se forma a partir das pequenas pátrias particulares, com características próprias e que conformam uma nação unida pela diferença. As críticas que ocorrem, e que devem continuar sendo válidas enquanto persistir o fenômeno, dizem respeito ao alto grau de conservadorismo e baixo grau de ecletismo que perpassa a cultura que busca na Guerra dos Farrapos o seu mito fundador. A construção da cultura hegemônica no Rio Grande do Sul diz respeito, assim como tudo em História, a disputas políticas e ideológicas.

A crítica à hegemonia do gauchismo no Rio Grande do Sul deve focar seu exame, ao meu entender, sobre um fenômeno que se alvoroça em tempos de crise: a crítica ao "outro", ao "ele", ao culpado por todos os nossos problemas, o de fora. Assim, a afirmação da identidade regional, sempre válida, não pode cair no âmbito da xenofobia, como temos presenciado, infelizmente, com certa frequência em nossa realidade atual. ${ }^{51}$

Depois de voltar para a Europa e estar lutando nas contendas da unificação italiana, Giuseppe Garibaldi escreveu uma carta para um antigo amigo farroupilha, em que pergunta: 
Quantas vezes tenho desejado nestes campos italianos um só esquadrão de vossos centauros avezados a carregar uma massa de infantaria com o mesmo desembaraço como se fosse uma ponta de gado. (...) Onde estão agora esses buliçosos filhos do Continente, tão majestosamente terríveis nos combates? Onde Bento Gonçalves, Neto, Canabarro, Teixeira e tantos valorosos que não lembro? ${ }^{52}$

Hoje, Garibaldi, estes senhores permeiam nossa imaginação, assim como tu, sendo utilizados em disputas identitárias e de reconhecimento. E por detrás de vocês, fileiras de cavalarianos e infantes anônimos pedem passagem, querendo desesperadamente ingressar no brete da memória.

\section{Notas}

1 Para uma análise das demais revoltas regenciais, ver: ASSUNÇÃO, Matthias R. "Sustentar a Constituição e a Santa Religião Católica, amar a Pátria e o Imperador”. Liberalismo popular e o ideário da Balaiada no Maranhão. In: DANTAS, Monica D. (org.). Revoltas, Motins, Revoluções: Homens livres pobres e libertos no Brasil do século XIX. São Paulo: Alameda, 2011, p. 296-327; e: PINHEIRO, Luís Balkar Sá Peixoto. Cabanagem: percursos históricos e historiográficos. In: DANTAS, Monica D. (org.). Revoltas, Motins, Revoluções: Homens livres pobres e libertos no Brasil do século XIX. São Paulo: Alameda, 2011. p. 201-228.

2 Para citarmos apenas o exemplo do maior e mais circulado veículo impresso do Rio Grande do Sul, o jornal Zero Hora, do Grupo RBS, pode-se concluir que durante o mês de setembro quase todos os seus "editoriais destinam espaço para esses acontecimentos, da cultura ao esporte, passando por política, opinião geral, economia, etc.” FELIPPI, Ângela. A identidade gaúcha no jornalismo impresso - o caso de Zero Hora. In: FILIPPI, Ângela; NECCHI, Vitor (Orgs.). Mídia e identidade gaúcha. Santa Cruz do Sul: EDUNISC, 2009.

3 Dois trabalhos podem ser destacados quando falamos de estudos voltados ao esclarecimento da invasão farroupilha a Santa Catarina e da existência da efêmera República Juliana. O primeiro deles, de Henrique Boiteux, é mais antigo e nele o autor se preocupa em fazer longas citações de documentos primários. O segundo trabalho, mais recente, de Gustavo Costa, faz uma análise mais detida sobre as particularidades sociais envolvidas na tentativa de formação de uma República autônoma em Santa Catarina: BOITEUX, Henrique. A República Catharinense: notas para sua história. Rio de Janeiro: Xerox, 1985; COSTA, Gustavo Marangoni. Entre Contrabandos e Ambigüidades: outros aspectos da República Juliana - Laguna/SC - 1836-1845. Florianópolis: UFSC, 2006 (Dissertação de Mestrado).

4 GUAZZELLI, César Augusto Barcelos. O horizonte da província: A República Rio-Grandense e os caudilhos do Rio da Prata (1835 - 1845). Rio de Janeiro: UFRJ, 1997 (Tese de Doutorado).

5 RECKZIEGEL, Ana L. História regional: dimensões teórico-conceituais. In: História: debates e tendências. Revista do Programa de Pós-graduação em História da UPF. Passo Fundo: UPF, 1999.

6 BOURDIEU, Pierre. O Poder Simbólico. Rio de Janeiro: Bertrand Brasil, 1989, p. 112.

7 Ibidem, p. 113. 
8 OLIVEN, Ruben George. A Parte e o Todo: a diversidade cultural no Brasil-nação. Petrópolis: Vozes, 2006.

9 BARROS, José D’Assunção. O Tempo dos Historiadores. Petrópolis: Vozes, 2013.

10 Anais do Arquivo Histórico do Rio Grande do Sul, vol. 5, CV-3190, p. 468.

11 LEITMAN, Spencer Lewis. Raízes Socioeconômicas da Guerra dos Farrapos: um capítulo na história do Brasil do século XIX. Rio de Janeiro: Edições Graal, 1979.

12 FARINATTI, Luís A. E. Confins meridionais: famílias de elite e sociedade agrária na fronteira sul do Brasil (1825-1865). Rio de Janeiro: UFRJ, 2007 (Tese de Doutorado).

13 COMISSOLI, Adriano. Ajudado por homens que lhe obedecem de boa vontade: considerações sobre laços de confiança entre comandantes e comandados nas forças militares luso-brasileiras no início dos oitocentos. In: COMISSOLI, Adriano; MUGGE, Miquéias (Orgs). Homens e Armas: recrutamento militar no Brasil, século XIX. São Leopoldo: Oikos, 2011, p. 25.

14 DOLHNIKOFF, Miriam. Elites regionais e a construção do Estado nacional. In: JANCSÓ, István (Org.). Brasil: formação do Estado e da Nação. São Paulo/Ijuí: Hucitec/FAPESP/ UNIJUÍ, 2003, p. 432.

15 SPALDING, Walter. A Revolução Farroupilha: história popular do grande decênio. São Paulo: Ed. Nacional, 1980, p. 6-7.

16 FERREIRA, Gabriela. Conflitos no Rio da Prata. In: GRINBERG, Keila; SALLES, Ricardo (Orgs.). O Brasil Imperial - Vol. I - 1808-1831. Rio de Janeiro: Civilização Brasileira, 2009 , p. 331.

17 PICCOLO, Helga I. O Processo de Independência do Brasil. In: BOEIRA, Nelson; GOLIN, Tau (Coords.). História Geral do Rio Grande do Sul - Vol. 2, Império. Passo Fundo: Méritos, 2006, p. 34.

18 AHRGS, Coletânea de Documentos de Bento Gonçalves da Silva, BG-420, p. 282.

19 MIRANDA, Márcia Echert. Rio Grande do Sul: tributação e economia (1699-1945). Porto Alegre: UFRGS, 1998, p. 69 (Dissertação de Mestrado).

20 Ibidem, p. 69-70.

21 LEITMAN, op. cit., 138-139.

22 GRAHAM, Richard. Clientelismo e politica no Brasil do século XIX. Rio de Janeiro: UFRJ, 1997, p. 82.

23 LEITMAN, op. cit., p. 58-61.

24 FARINATTI, op. cit., p. 186-187.

25 SPALDING, Walter. A Epopéia Farroupilha. (Pequena História da Grande Revolução, acompanhada de farta documentação da época - 1835-1845). Rio de Janeiro: Ed. da Biblioteca do Exército, 1963.

26 KLAFKE, Álvaro Antonio. Antecipar essa idade de paz, esse império do bem: imprensa periódica e discurso de construção do Estado unificado (São Pedro do Rio Grande do Sul, 1831-1845). Porto Alegre: UFRGS, 2011, p. 88-90 (Tese de Doutorado).

27 CAGGIANI, Ivo. Canabarro: de tenente a general. Porto Alegre: Martins Livreiro, 1992. 28 O POVO, Piratini, 1838. Caçapava, 1839. Ed. fac-similada da Livraria do Globo, 1930. 
29 CASTRO, Jeanne Berrance de Castro. A milícia cidadã: a Guarda Nacional de 1831 a 1850. São Paulo: Ed. Nacional, 1979; FARIA, Maria Auxiliadora. A Guarda Nacional em Minas (1831-1873). Curitiba: Universidade Federal do Paraná, 1977 (Dissertação de Mestrado). RIBEIRO, José Iran. Quando o serviço os chamava: milicianos e Guarda Nacional no Rio Grande do Sul (1825-1845). Santa Maria: Editora da UFSM, 2005.

30 GIL, Tiago. Infiéis Transgressores: elites e contrabandistas nas fronteiras do Rio Grande e do Rio Pardo (1760-1810). Rio de Janeiro: Arquivo Nacional, 2007.

31 FLORES, Moacyr. Modelo Político dos Farrapos: as idéias políticas da revolução farroupilha. Porto Alegre: Mercado Aberto, 1982, p. 159-165.

32 BRITO, Francisco de Sá. Memórias da Guerra dos Farrapos. Porto Alegre: CORAG, 1986; FLORES, Moacyr. Modelo Politico dos Farrapos: as idéias políticas da revolução farroupilha. Porto Alegre: Mercado Aberto, 1982; PADOIN, Maria Medianeira. Federalismo Gaúcho: Fronteira Platina, Direito e Revolução. São Paulo: Companhia Editora Nacional, 2001.

33 Ibidem.

34 FLORES, op. cit.

35 A dissertação de Jeferson Mendes trata das táticas utilizadas pelo então Barão de Caxias durante o conflito, passando por formas de abastecimento e táticas militares. Já o livro de Tau Goin relata as intrigas que eram realizadas pelo Barão, buscando minar internamente o já muito fragilizado grupo farroupilha: MENDES, Jeferson dos Santos. O barão de Caxias na guerra contra os farrapos. Passo Fundo: UPF, 2011 (Dissertação de Mestrado); GOLIN, Tau. A tradicionalidade na cultura e na história do Rio Grande do Sul. Porto Alegre: Tchê!, 1989.

36 Anais do Arquivo Histórico do Rio Grande do Sul, vol. 11, CV-6000, CV-6001, p. 56-59. Trata-se da relação de valores entregues a lideranças farroupilhas para o aceite da anistia imperial. Antônio Vicente da Fontoura organizava a distribuição dos valores, entretanto, nem seu inimigo figadal, Domingos José de Almeida, deixou de receber 2:000\$000 (dois contos de réis).

37 Trata-se de uma batalha ocorrida na madrugada de 14 de novembro de 1844 , no Cerro de Porongos, atual município de Pinheiro Machado. Documento encontrado posteriormente aponta que houve uma combinação entre o chefe farroupilha, David Canabarro, e o comandante legalista, para que ocorresse uma chacina dos negros que estavam defendendo os farroupilhas. Ver: FLORES, Moacyr. Negros na Revolução Farroupilha: traição em Porongos e farsa em Ponche Verde. Porto Alegre: EST, 2004; SILVA, Juremir Machado da. História regional da infâmia: o destino dos negros farrapos e outras iniquidades brasileiras (ou como se produzem os imaginários). Porto Alegre: L\&PM, 2010.

38 GOLIN, Tau. A tradicionalidade na cultura e na história do Rio Grande do Sul. Porto Alegre: Tchê!, 1989.

39 CARVALHO, Daniela Vallandro de. Fronteiras da Liberdade: Experiências Negras de Recrutamento, Guerra e Escravidão - (Rio Grande de São Pedro, c. 1835-1850). Rio de Janeiro: UFRJ, 2013 (Tese de Doutorado).

40 FLORES, Moacyr. Negros na Revolução Farroupilha: traição em Porongos e farsa em Ponche Verde. Porto Alegre: EST, 2004.

41 SILVA, Juremir Machado da. História regional da infâmia: o destino dos negros farrapos e outras iniquidades brasileiras (ou como se produzem os imaginários). Porto Alegre: L\&PM, 2010; CARVALHO, Daniela Vallandro de. Fronteiras da Liberdade: Experiências Negras 
de Recrutamento, Guerra e Escravidão - (Rio Grande de São Pedro, c. 1835-1850). Rio de Janeiro: UFRJ, 2013 (Tese de Doutorado).

42 Pode-se alocar entre estes trabalhos o de Tasso Fragoso, ainda na primeira metade do século passado: FRAGOSO, Tasso. A Revolução Farroupilha (1835-1845). Rio de Janeiro: Biblioteca Militar, 1939.

43 Entre estes trabalhos destaca-se o de Moacyr Flores: FLORES, Moacyr. Modelo Político dos Farrapos: as idéias políticas da revolução farroupilha. Porto Alegre: Mercado Aberto, 1982.

44 Talvez o principal trabalho de Levi que tem influenciado teórico e metodologicamente as análises da Nova História Militar, seja: LEVI, Giovanni. A Herança Imaterial: trajetória de um exorcista no Piemonte do século XVII. Rio de Janeiro: Civilização Brasileira, 2000.

45 Podemos apontar, a título de exemplo, os seguintes trabalhos: RIBEIRO, op. cit.; RIBEIRO, José Iran. "De tão longe para sustentar a honra nacional”: Estado e Nação nas trajetórias dos militares do Exército Imperial brasileiro na Guerra dos Farrapos. Rio de Janeiro: UFRJ, 2009 (Tese de Doutorado). CARVALHO, op. cit.; FARINATTI, op. cit.; SCHMITT, Anderson M. "Não admitindo escusa alguma": confiscos e recrutamentos na guerra civil rio-grandense (1835-1845). Passo Fundo: UPF, 2014 (Dissertação de Mestrado).

46 RIBEIRO, op. cit.; COMISSOLI, op. cit.

47 SPALDING, Walter. A Epopéia Farroupilha. (Pequena História da Grande Revolução, acompanhada de farta documentação da época - 1835-1845). Rio de Janeiro: Ed. da Biblioteca do Exército, 1963.

48 Podemos afirmar que o cabedal militar "era formado exatamente por sua capacidade de conseguir homens, cavalos, suprimentos, por seu conhecimento das guerras do sul, por suas relações com lideranças platinas. Um cabedal militar sólido embasava o grau de autonomia relativa desses comandantes, ou seja, suas possibilidades de posicionar-se nas guerras e alianças instáveis do sul, de se tornar um aliado desejável para os lados em luta, de poder negociar sua entrada nas guerras de forma que considerasse mais adequada e vantajosa." FARINATTI, op. cit., p. 179-180.

49 LEVI, Giovanni. Sobre a micro-história. In: BURKE, Peter (org.). A escrita da História: novas perspectivas. São Paulo: UNESP, 1992, p. 135.

50 LE GOFF, Jacques. História e memória. Campinas: UNICAMP, 1993.

51 Em abril de 2014, o prefeito de Carlos Barbosa, na serra gaúcha, teria dito durante uma festividade no município que uma "infestação de baianos e goianos traria fome" à cidade. O município ocupava o $1^{\circ}$ lugar no ranking do Índice de Desenvolvimento Socioeconômico no Rio Grande do Sul. Fonte: http:/g1.globo.com/rs/rio-grande-do-sul/noticia/2014/04/infestacao-de-baianos-e-goianos-traria-fome-diz-prefeito-no-rs.html

52 PORTO ALEGRE A. Vultos e fatos do Rio Grande do Sul. Porto Alegre: Globo, 1919.

Recebido em 02/03/2017

Aceito em 04/08/2018 